\title{
EEN CONFLICT TUSSCHEN AMSTERDAM EN DE STATEN-GENERAAL OVER SURINAME IN 1774 en 1775
}

\author{
DOOR \\ C. K. KESLER \\ II (Slot)
}

Mr. De Vrij Temminck was een tegenstander, waarmede de Oranjepartij rekening moest houden, vooral, daar hij staat kon maken op de medewerking zijner ambtgenooten ${ }^{1}$ ) en van den Pensionaris der stad Mr. E. F. van Berckel, die kort na de in dit artikel vermelde gebeurtenissen een belangrijk aandeel zou nemen in de onderhandelingen over het sluiten van een handelsverdrag met de opgestane Engelsche koloniën in Amerika. Bij de burgerij was hij zeer gezien, waartoe veel bijdroeg, dat hij in den omgang een zekere familiariteit aan den dag legde, die soms zelfs wel in platheid van uitdrukking overging.

In het schrijven van Amsterdam aan de Staten-Generaal werd de nadruk erop gelegd, dat het besluit tot het zenden van hulptroepen genomen was, terwijl slechts de afgevaardigden van twee provinciën opdracht hadden,

1) Zijn ambtgenooten waren in $1774 \mathrm{Mr}$. Gualtherus Petrus Boudaen, Henrick Hooft Dz. en Jan van Tarelink. De eerste was gehuwd met Catharina Margaretha Romswinckel, die van haar vader de schoone hofstede Elswout bij Haarlem erfde. Burgemeester Boudaen liet deze belangrijk uitbreiden en verfraaien. Bij zijndood werd zij op een waarde van $f 36.000$ getaxeerd.

H. Hooft Dz. was o.a. eigenaar van koffie-, katoen- en cacaoplantages met 200 slaven in Berbice. In 1773 werden deze te Amsterdam geveild en opgehouden voor $f 20.000$. Jan van Tarelink was vooral geïnteresseerd in de walvischvangst. De Tarelinks komen gedurende een reeks van jaren voor als Directeuren van de Groenlandsche visscherij en die op Str. Davis. In 1781 ging de firma J. \& Ch. van Tarelink failliet en sedert maakten de Tarelinks geen deel meer uit van de vroedschap. 
ervoor te stemmen. Op grond hiervan beschouwde Amsterdam het genomen besluit als onwettig en verklaarde, in het vervolg steeds tegen een dergelijke behandeling der zaken te zullen protesteeren. De verdere ontwikkeling van het geschil maakte, dat ten slotte Amsterdam in zijn verzet geheel alleen stond. 1 November 1774 verklaarde Overijssel zich bereid tot betaling van $f 500.000$ voor de zending der eerste troepen en van $f 100.000$ voor de versterking en achtereenvolgens kwamen ook de bereidverklaringen van Gelderland ${ }^{1}$ ), Friesland, Stad en Lande, Utrecht en Zeeland in.

Inmiddels hadden in de Staten van Holland de Ridderschap en de 17 overige steden tegen Amsterdam stelling genomen, maar dit bleef bij zijn weigering. Om een vergelijk mogelijk te maken, werd toen door de Ridderschap voorgesteld, de zaak te doen behandelen door het Groot Besogne," daar het eene zaak van verre uitzigt was en voor de onverdeelbare Souvereiniteit van Hunne Ed. Groot Mogenden niet onverschillig konde zijn." Dit Groot of Geheim Besogne was een college, bestaande uit den

1) $\mathrm{Bij}$ de toestemming van Gelderland was een protest gevoegd van het lid der Staten Robert Jasper Baron van der Capelle, heer van de Marsch. Deze was lid van de Ridderschap van Zutfen en een neef van Johan Derk van der Capelle, heer van de Poll. Beiden waren bekend als felle Patriotten. De laatste interesseerde zich o.a. voor een betere behandeling der slaven en betoogde, dat, al waren er enkele, zoo zij als eens naar de Republiek kwamen, daar ook vrij, zij toch weer in slavernij raakten, als zij door hun meester naar Suriname teruggevoerd werden. Zooals bekend is, was de vrijheid voor slaven bij overkomst naar Holland door Stadhouder Willem IV aan den bekenden Kwassie toegezegd. Dat de meesters zich daaraan niet veel stoorden blijkt wel uit het geval van Baron, die, hoewel zijn meester, de $Z$ weed Dahlberg hem mede naar Holland genomen had, toch later door dezen verkocht werd. Stedman verhaalt, dat deze Dahlberg in Suriname gekomen was met twee zilverstukjes als eenige bezitting en o.a. door tooverkunsten en dergelijke bedriegerijen fortuin gemaakt had. Zijn oorspronkelijk kapitaal, de beide zilveren muntjes, bewaarde hij als relequie met goud en diamanten omzet.

Van der Capelle van de Marsch werd na de Pruissische interventie in 1788 bij verstek ter dood veroordeeld. Hij was het vorige jaar naar de $Z$. Nederlanden en vandaar naar Frankrijk gevlucht. Zijn portret door Reinier Vinkeles komt voor in het derde deel van het vervolg op Wagenaar

Zijn neef Van der Capelle van de Poll was in 1784 overleden en overeenkomstig zijn wensch op een zijner landgoederen op de heide begraven. 7 Aug. 1788 lieten Prinsgezinden het grafmonument met kruit in de lucht springen. 
Stadhouder, als voorzitter, en 9 à 11 leden, n.l. één tot drie uit Holland, één uit ieder der overige gewesten, den raadpensionaris van Holland en den griffier der StatenGeneraal. Sedert ongeveer 1630 was het gewoonte geworden, spoedvereischende buitenlandsche zaken en die, waarbij geheimhouding, die bij een behandeling in de Staten-Generaal allerminst gewaarborgd was, wenschelijk bleek, door dit college te doen afhandelen.

Overeenkomstig het voorstel der Ridderschap werd gehandeld en, wat te voorzien was, geschiedde, de houding van Amsterdam werd scherp afgekeurd en het Bestuur der stad aangemaand, alsnog het genomen besluit in te trekken. Dit geschiedde o.a. in deze bewoordingen: „Ridderschap en verdere Gecommitteerden overwogen hebbende, door hoedanige, meest kragtdadige middelen het nadeelig effect van de voor het gezag en de belangen van den Staat zoo gevaarlijke en verre uitziende onderneming van de Stad Amsterdam, door de inhouding van een gedeelte van 's Lands penningen, geprevenieerd zouden kunnen worden, Hun Ed. Groot Mogenden hadden goedgevonden dat aan Heeren Burgemeesteren en Regeerders der Stad Amsterdam de onwettigheid van 't geen bij hen ter zaake voorsz. is gedaan en ondernomen, bij Missive in de kragtigste bewoordingen zal worden voorgehouden, en dat dezelve daar benevens op het ernstigste zullen worden aangespoord, om de gedąane afkorting van 'sLands penningen op 't spoedigste te vergoeden, en het nadeelige uitwerksel hunner onderneeminge, hoe eerder hoe beter, doen verdwijnen."

Burgemeesters van Amsterdam waren echter geenszins geneigd toe te geven; integendeel, zij maakten er thans een kwestie van staatsrecht van. $\mathrm{Zij}$ verzetten zich ertegen, dat telkens, vooral door de Ridderschap op den voorgrond gesteld werd, dat de houding van Amsterdam onwettig was, dus, dat daarover niet gedelibereerd behoorde te worden, en, dat alleen naar middelen gezocht werd om de stad tot toegeven te dwingen. Na eerst betoogd te hebben, dat tusschen de verschillende adviezen van de Ridderschap in deze zaak tegenspraak was en erop gewezen 
te hebben, dat deze de houding van Amsterdam niet had te beoordeelen, nu de beslechting van het geschil aan het Groot Besogne was opgedragen, en haar verweten te hebben, de stad te behandelen, alsof deze niet een ,,integreerend Lid van de Souverainiteit was", beriepen Burgemeesters zich op art. 14 van de Unie, luidende: „Dat het eene Lidmaat of het andere van de Staaten niet en zal worden overstemt tegens zijne wille of advis; of met de meeste stemmen overwonnen in materie van Consent te dragen tot Beden, Suventiën ofte van eenige partijen of gedeelten van Contributie onder malkanderen te maaken, of op het vinden van een middel van dien."

Bovendien hadden de afgevaardigden der overige 17 steden gestemd zonder uitdrukkelijken last van de besturen, die hen hadden afgevaardigd, waardoor volgens Amsterdam het genomen besluit onwettig was. Het beriep zich hierbij op een besluit van de Staten van Holland van 16 October 1587, waarin ruggespraak met de lastgevers voor een stemming uitdrukkelijk werd voorgeschreven. In dit stuk, getiteld: „Korte vertooning van het regt bij de Ridderschap, Edelen en Steden van Holland, van alle oude tijden in de voorsz. Landen gebruikt tot behoudenis van de Vrijheden, Geregtigheden, Privilegiën en loffelijke gebruiken van denzelven Landen," was deze zaak aldus omschreven: ,dat de voornoemde Gecommitteerden bijzonder gelast zijn, de Regten, Vrijheden en Privilegiën van den Lande te maintineeren en alle inbreuken te weeren en te wederstaan, en dat deese Gecommitteerden alzulks bij den anderen vergaderende representeeren de Staaten van den zelve Lande. N. B. Niet dat zij luyde in haar Persoonen, ofte uit haar authoriteit, de Staaten zijn, maar alleen uit kragte van haare Principaalen."

Amsterdam was dus geenszins geneigd toe te geven. Integendeel, het kondigde in hetzelfde schrijven aan, zich ertegen te zullen verzetten, dat voor buitengewone uitgaven ten behoeve van Suriname zou geput worden uit het „Fonds van de Extraordinaire middelen van deezen loopenden jaare." Het was duidelijk, dat, in weerwil van het zeer welwillende slot van de missive:" Hiermede 
Edele Groot Mogende Heeren, God Almachtig biddende UEd. enz.", Burgemeesters niet van plan waren, een duimbreed van hun standpunt prijs te geven.

Toch werden ten slotte de vereischte gelden door Amsterdam toegestaan en was zelfs de provincie Holland de eerste, die een belangrijke remise naar Suriname overmaakte en wel een bedrag van $f$ 139.220, dat 8 December 1777 te Paramaribo aankwam. Burgemeesters hadden toegegeven, zonder echter in een enkel opzicht hun standpunt te wijzigen. Er waren n.l. andere berichten ingekomen, waardoor zij bekend geworden waren met de oneenigheden tusschen , den Commandeerenden Officier van de Troupes en de Regeeringe van de Colonie" en met de bovenvermelde, dreigende moeilijkheden met de Saramaccaners. In de verschillen tusschen Nepveu en Fourgeoud koos Amsterdam, wat de kwestie van het cordon betreft, voorloopig de zijde van den Gouverneur. En tegenover de Saramaccaners wenschte het van Fourgeoud krachtiger optreden," om deze Lieden wederom te brengen tot hunnen pligt en tot den vereischten eerbied voor de gemelde Regeeringe, welke zij thans scheenen verlooren te hebben."

Omtrent de verdere wijze van optreden tegen de Marrons achtten Burgemeesters, overeenkomstig de voorstellen van Nepveu wenschelijk ,het formeeren van een Cordon van defensie, hetwelk bezet met de Troupen van de Colonie, de Plantagiën zoude dekken tegen de Invasie der Wegloopers en Bosch-Negers en uit hetwelk, gedurrende den droogen tijd, de noodige harceleering en excursiën tegen het overschot der Wegloopers zouden kunnen worden gedaan; om dezelven verder te kunnen ruineeren en uit te roeyen."

Daar de oneenigheden tusschen de voornaamste personen in de kolonie ,een gantsch nieuw object van deliberatie" uitmaakten, durfden de afgevaardigden van Amsterdam niet voor hun rekening nemen , de gevolgen, dewelke zouden kunnen proflueeren uit een verhaast rappel van de gemelde Troupes, in de staat, waar in de zaaken tegenswoordig, door gemelde dissensiën vervallen kunnen wezen." 
Feitelijk gaven Burgemeesters ten slotte dus toe, maar erkennen wilden zij dat volstrekt niet. Zij waren ervan overtuigd, dat het cordon geld zou kosten en dat dit eveneens het geval zou zijn met het onderhouden van een extra krijgsmacht in Suriname. Daarom verklaarden zij zich bereid, ,,vermits den slegten staat van de Cassen, zoo van de Societeit van Suriname, als van de Colonie, mede te contribueeren de Penningen, die gerequireert zullen worden, zoo tot het formeeren van het voorsz. Cordon,als tot het verblijf der Troupes in de Colonie." Doch zij dachten er niet aan, het genomen besluit omtrent de inhouding der bijdrage in te trekken, want zij verklaarden uitdrukkelijk, dat zij „persisteerden bij hun anterieur gedrag" en wilden zich in geen geval ,exponeeren aan schijnbaare tegenstrijdigheid, of ten minste aan dubbelzinnigheid in hunne gehoudene conduite." De noodige gelden werden dus toegestaan, of, zooals Burgemeesters het uitdrukten, ,de voorsz. inhouding van Penningen zou worden buiten effect gesteld."

Ten slotte had dus de tegenpartij in de Staten van Holland het pleit gewonnen, maar zij kon niet nalaten, op te merken, dat zij tot vergeven en vergeten in geenen deele bereid was. Hoewel er niet veel anders opzat, dan de contributie van Amsterdam te aanvaarden, vonden de afgevaardigden der Ridderschap, Dordrecht, Haarlem, Delft Leiden, Gouda en verdere leden het toch noodig, te verklaren, dat zij zich bij de zaak neerlegden, ,zonder te erkennen of eenigszins te wettigen de raisonnementen en illatie bij het vorenstaande Declaratoir van de Heeren Gedeputeerden van Amsterdam gemaakt en geavanceerd"'

Amsterdam wilde echter toch nog het laatste woord hebben, want bij de betaling, ingevolge bevelschrift van H. H. Regeerders van Amsterdam op 27 September 1775 werd er nog eens aan herinnerd, dat deze alleen geschiedde „om te redens en tot het einde bij Stads Declaratoir vermeld."

Nieuwer-Amstel. 